\title{
Plant densities and modulation of symbiotic nitrogen fixation in soybean
}

\author{
Marcos Javier de Luca ${ }^{1,2,3}$, Mariangela Hungría ${ }^{2,3 *}$
}

${ }^{1}$ National Institute of Agricultural Technology (INTA), Rivera Indarte $722^{\circ} 216$ - 5000 - Córdoba - Argentina.

Embrapa Soybean, C.P. 231 - 86001-970 - Londrina, PR - Brazil.

${ }^{3}$ State University of Londrina - Dept. Microbiology, C.P. 60001 - 86051-990 - Londrina, PR - Brazil.

*Corresponding author <mariangela.hungria@embrapa.br>

Edited by: Lincoln Zotarelli

Received August 26, 2013

Accepted January 06, 2014

\begin{abstract}
Soybean nitrogen (N) demands can be supplied to a large extent via biological nitrogen fixation, but the mechanisms of source/sink regulating photosynthesis/nitrogen fixation in high yielding cultivars and current crop management arrangements need to be investigated. We investigated the modulation of symbiotic nitrogen fixation in soybean [Glycine max (L.) Merrill] at different plant densities. A field trial was performed in southern Brazil with six treatments, including non-inoculated controls without and with $\mathrm{N}$-fertilizer, both at a density of 320,000 plants ha $^{-1}$, and plants inoculated with Bradyrhizobium elkanii at four densities, ranging from 40,000 to 320,000 plants ha- ${ }^{-1}$. Differences in nodulation, biomass production, $\mathrm{N}$ accumulation and partition were observed at stage R5, but not at stage V4, indicating that quantitative and qualitative factors (such as sunlight infrared/red ratio) assume increasing importance during the later stages of plant growth. Decreases in density in the inoculated treatments stimulated photosynthesis and nitrogen fixation per plant. Similar yields were obtained at the different plant densities, with decreases only at the very low density level of 40,000 plants ha $^{-1}$, which was also the only treatment to show differences in seed protein and oil contents. Results confirm a fine tuning of the mechanisms of source/sink, photosynthesis/nitrogen fixation under lower plant densities. Higher photosynthesis and nitrogen fixation rates are capable of sustaining increased plant growth. Keywords: Glycine max, biological nitrogen fixation, photosynthesis, source/sink manipulation, plant density
\end{abstract}

\section{Introduction}

Soybean [Glycine $\max (\mathrm{L}$.) Merrill] is an important global agribusiness commodity. In Brazil, this legume is produced in an area covering 25 million hectares, including remote areas.It persists as one of the most profitable crops, mainly because its nitrogen $(\mathrm{N})$ requirements are met by symbiotic nitrogen fixation (Hungria et al., 2005, 2006a, 2006b). In the soybean-Bradyrhizobium symbiosis, the plant supplies the bacteria with photosynthates $(\mathrm{C})$ via phloem and receives $\mathrm{N}$ from fixation via xylem (e.g. Neves and Hungria, 1987; Williams et al., 1982). Symbiotic nitrogen fixation consumes 6-12 $\mathrm{g} \mathrm{C} \mathrm{g}^{-1}$ of fixed $\mathrm{N}$, representing about $20-30 \%$ of the total plant photosynthesis; however, this strong sink for $\mathrm{C}$ does not necessarily reduce yield, because it may modulate source activity (photosynthesis) (Kaschuk et al., 2009, 2010, 2012).

Soybean plant densities of 400,000 plants ha- ${ }^{-1}$ (Embrapa Soja, 2011) or even higher (National Soybean Research Laboratory, 2012) are recommended. However, at lower densities, interplant competition for water, nutrients and light could be mitigated (Andrade et al., 2002; Blumenthal et al., 1988). Conversely, at high densities shaded leaves may not contribute to canopy photosynthesis (Board et al., 1990, 1992), and will likely senesce and/or be susceptible to disease (Pons and Pearcy, 1994). Furthermore, the lack of light penetration to deeper layers of the canopy may decrease yields (Stockman and Shibles, 1986). Finally, changes in the red/infrared ratios through the canopy may deeply affect both photosynthesis (Kasperbauer, 1987), and the onset of nodule formation (Lie, 1969).
Symbiotic nitrogen fixation is an overwhelming sink for photosynthate and may limit yield (Kaschuk et al., 2009, 2010; Neves and Hungria, 1987). However, plants can increase photosynthesis rates to support increasing sinks (Kaschuk et al., 2009, 2012; Paul and Foyer, 2001). It remains to be determined to what extent source/sink relationships can be up-regulated. In addition to the $\mathrm{C}$ requirements for nitrogen fixation and yield, soybean photosynthesis has to supply high $\mathrm{C}$ sinks from the seeds to lipid and protein accumulation (Kaschuk et al., 2010; Penning de Vries et al., 1974).

In this study we report results from a field experiment aimed at determining the effects of plant density on nitrogen fixation, yield, plus lipid and protein contents of soybean in connection with the relationship between source activity and sink strength. The hypothesis was that different plant densities might not affect grain yield and quality, and as a "compensatory mechanism" lead to increases in both photosynthesis and nitrogen fixation rates.

\section{Materials and Methods}

\section{Field site description}

The experiment was performed in the summer season of 2009/2010 in Londrina, in the state of Paraná (PR), Brazil $\left(23^{\circ} 11^{\prime} \mathrm{S} ; 51^{\circ} 11^{\prime} \mathrm{W}, 620 \mathrm{~m}\right.$ a.s.l.). The soil is classified as Latossolo Vermelho Distroférrico (Brazilian classification system; Typic Haplustox, USA taxonomy). The average annual temperature in Londrina is $21^{\circ} \mathrm{C}$, with an average maximum of $28.5^{\circ} \mathrm{C}$ in $\mathrm{Feb}$ and a minimum of $13.3^{\circ} \mathrm{C}$ in July. Average annual rainfall is 1,651 $\mathrm{mm}$, with 123 days of rainfall per year; maximum rain- 
fall occurs in the summer (Jan-Mar) and the minimum in winter (June-Aug). According to Köeppen's classification, the climate in Londrina is subtropical humid (Cfa: humid, subtropical, with hot summers). Daily average temperature and daily rainfall during the experiment and their averages between 1998-2012 are shown in Figure 1.

Lime had most recently been applied to the area in 2008. Chemical analysis of the soil $(0-20 \mathrm{~cm}$ layer, samplings made 30 days before sowing) resulted in the following characteristics immediately before sowing: $\mathrm{pH}$ $\left(0.01 \mathrm{M} \mathrm{CaCl}_{2}\right), 5.21 ; \mathrm{H}+\mathrm{Al}, 37.1\left(\mathrm{mmol}_{\mathrm{c}} \mathrm{dm}^{-3}\right) ; \mathrm{Al}, 0.7$ $\left(\mathrm{mmol}_{\mathrm{c}} \mathrm{dm}^{-3}\right)$; $\mathrm{P}, 13.43\left(\mathrm{mg} \mathrm{dm}^{-3}\right): \mathrm{K}, 6.4\left(\mathrm{mmol}_{\mathrm{c}} \mathrm{dm}^{-3}\right)$; $\mathrm{C}, 18 \mathrm{~g} \mathrm{dm}^{-3} ; \mathrm{Ca}+\mathrm{Mg}$, $75.6\left(\mathrm{mmol}_{\mathrm{c}} \mathrm{dm}^{-3}\right)$; base saturation, $69 \%$. The soybean bradyrhizobia population in the soil was estimated by the most probable number (MPN) method using soybean plants (Vincent, 1970).

\section{Treatments, experimental design and crop manage- ment}

Before sowing, the soil was prepared using the traditional practices of ploughing and disking. At sowing, the area received $300 \mathrm{~kg} \mathrm{ha}^{-1}$ of fertilizer of $0-20-20$ formulation. The commercial cultivar BRS 133 (genealogy: FT Abyara $\times$ BR83-147; maturity group 7.3, determinate type of growth) was shown on the $4^{\text {th }}$ of November of 2009.

The experiment consisted of six treatments: T1) Non-inoculated control, with $50 \mathrm{~cm}$ between sowing lines and 16 plants $\mathrm{m}^{-1}(0.5 \times 16$ plants $)(320,000$ plants ha $^{-1}$ ) (C); T2) Non-inoculated control $+\mathrm{N}$-fertilizer (200 $\mathrm{kg} \mathrm{N} \mathrm{ha}^{-1}$, as urea, $50 \%$ applied at sowing and $50 \%$ at $\mathrm{R} 2$, broadcast, sown at $0.5 \times 16$ plants $)(320,000$ plants ha $\left.^{-1}\right)(\mathrm{C}+\mathrm{N})$; T3) Inoculated, with $50 \mathrm{~cm} \times 4$ plants per linear meter $(0.5 \times 4$ plants $)\left(80,000\right.$ plants ha $\left.^{-1}\right)$; T4) Inoculated, with $50 \mathrm{~cm} \times 16$ plants $(0.5 \times 16$ plants $)$

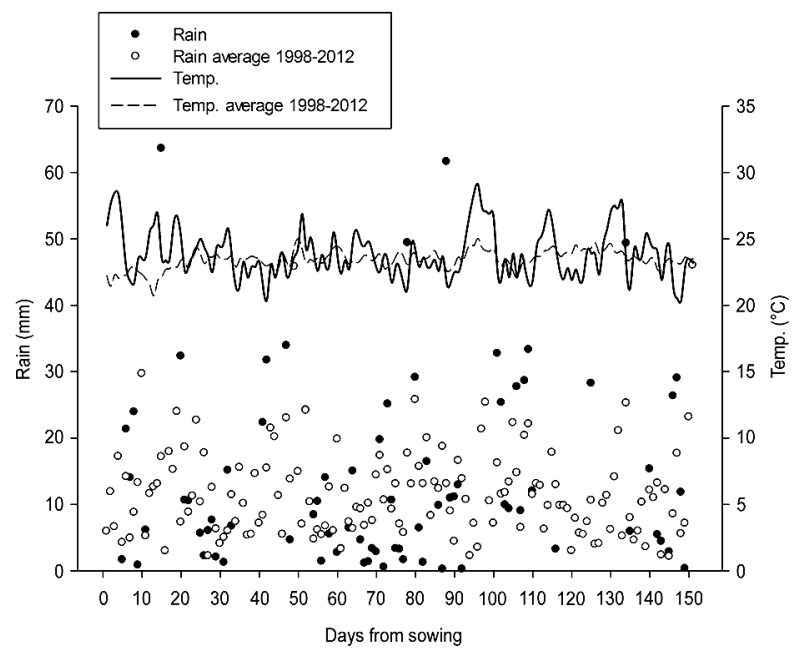

Figure 1 - Daily average temperature and daily rainfall during the experiment and their averages between 1998-2012.
$(320,000$ plants ha-1); T5) Inoculated, with $1.0 \mathrm{~m}$ between lines and 4 plants per linear meter $(1.0 \times 4$ plants $)$ $\left(40,000\right.$ plants ha $\left.\left.{ }^{-1}\right) ; \mathrm{T} 6\right)$ Inoculated, with $1.0 \mathrm{~m}$ between lines and 16 plants per linear meter $(1.0 \times 16$ plants $)$ $\left(160,000\right.$ plants ha $\left.{ }^{-1}\right)$. Each plot measured $4 \mathrm{~m}$ in width by $6 \mathrm{~m}$ in length. The experiment had a completely randomized block design, with six replicates.

Seeds were not treated with fungicides or insecticide. Inoculation in treatments 3 to 6 consisted of adding peat inoculant $\left(10^{9} \mathrm{CFU} \mathrm{g}^{-1}\right)$ containing B. elkanii commercial strains SEMIA 587 and SEMIA 5019 l= 29W). A $10 \%$ sugar solution was used as an adhesive and the inoculant was applied to supply a theoretical concentration of 1.2 million cells seed ${ }^{-1}$, following the technical recommendation for the crop in Brazil (Embrapa, 2011; Hungria et al., 2007). At the V4 stage all treatments were sprayed with $20 \mathrm{~g} \mathrm{ha}^{-1}$ of Mo, as per recommendation (Embrapa, 2011; Hungria et al., 2007). The following products were used: herbicides: Clorimuron $\left(50 \mathrm{~g} \mathrm{ha}^{-1}\right)$ and Cletodim $\left(0.4 \mathrm{~L} \mathrm{ha}^{-1}\right)$; insecticides: Diflubenzuron (80 $\left.\mathrm{g} \mathrm{ha}^{-1}\right)$, Thiametoxam + Lambdacihalotrina $\left(200 \mathrm{cc} \mathrm{ha}^{-1}\right)$. Rainfall provided moisture as shown in Figure 1.

Soil sampling, harvest, plant analyses and statistics Samplings were performed at three growth stages (Fehr et al., 1971): V4 (four unfolded trifoliolate leaves), $\mathrm{R} 5$ (seeds are $3 \mathrm{~mm}$ long in the pod at one of the four uppermost nodes on the main stem) and R8 (full maturity). At stages V4 and R5, eight plants per replicate were randomly harvested, excluding the central area 8 $\mathrm{m}^{2}$ ) of the plot determined to be used for yield evaluation. Harvesting of plants was carefully carried out with a shovel to include most of the root system so as to verify falling nodules; the whole plant was taken to the laboratory. Procedures at the laboratory to evaluate nodulation, shoot dry weight and total $\mathrm{N}$ in tissues were implemented as previously described (Hungria et al., 2006b). At V4 and R5, the parameters evaluated were nodulation (nodule number and dry weight), and shoot dry weight, while the dry weight of leaflets (presented apart from the whole shoot dry weight) was evaluated only at R5. Nitrogen content was evaluated by Kjeldahl's digestion at V4 in shoots (leaves + stems) and at R5 in shoots and pods.

At the final harvest $\left(8 \mathrm{~m}^{2}\right.$ harvested in the central part of each replicate), the parameters estimated were number of plants $\mathrm{m}^{-2}$, yield (corrected to $13 \%$ of moisture), dry weight of 100 grains (also corrected to $13 \%$ of moisture), number of grains per plant ${ }^{-1}$, and $\mathrm{N}$ and oil contents of the grains. Lipid content (oil) in grains was determined in milled seeds in a Soxhlet extractor, using $\mathrm{n}$-hexane as the solvent and following the methodology of Zenebon (2008).

The data were analyzed using the Infostat SAS statistical package (Di Rienzo et al., 2009). All assumptions required by the analysis of variance were verified. Means were analyzed using Fisher's test. 


\section{Results}

The soil presented a high population of soybean bradyrhizobia, estimated at $2.871 \times 10^{4} \mathrm{CFU} \mathrm{g}^{-1}$ soil (MPN method). The naturalized bradyrhizobial population produced good nodulation [nodule number per plant (NN), dry weight per nodule (DWN) and nodule dry weight per plant (NDW)] even in the non-inoculated control (T1) (Table 1). Inhibitory effects of chemical Nfertilizer (T2) on nodulation parameters were clearly observed at V4 and R2 stages (Table 1).

In the comparison of the non-inoculated treatment (T1) with the inoculated treatment of the same plant density of 320,000 plants $\mathrm{ha}^{-1}(\mathrm{~T} 4)$, there was an increase in dry weight per nodule $(p<0.0001)$ at V4 (Table 1), associated with large nodules at the root crown. At R5, no differences were detected in the comparison of the inoculated treatments with densities of $0.5 \times 4$ plants (T3) and $1.0 \times 4$ plants (T5), but these two treatments were superior $(p<0.0001)$ to the treatments with 0.5 $\times 16$ plants $(\mathrm{T} 4)$ and $1.0 \times 16$ plants (T6), both in nodule number and in dry weight parameters (Table 1). Additionally, higher leaf production was observed in both treatments with 4 plants per linear meter (T3 and $\mathrm{T} 5$ ) (Figure 2).

Shoot dry weight (SDW) values are also shown in Table 1. Similarly, nodulation data, at V4 differences between inoculated treatments under different plant densities were not significant, whereas, at $\mathrm{R} 5$ the same treatments, $0.5 \times 4$ plants (T3) and $1.0 \times 4$ plants (T5), were similar and higher than for treatments $0.5 \times 16$ plants (T4) and $1.0 \times 16$ plants (T6) (Table 1).

Patterns of $\mathrm{N}$ accumulation in shoots and pods at R5 (Figure 3) were similar to the results for nodulation and plant biomass production (Table 1). In Figure 3 , emphasis should be given to the values of $\mathrm{N}$ in pods at R5, which confirm the superiority of the inoculated treatments with lower numbers of plants per meter, 0.5 $\times 4$ plants and $1.0 \times 4$ plants It was also possible to establish a linear relationship between the parameters of plant biomass and $\mathrm{N}$ accumulation in plants both at
V4 $\left(R^{2}=0.95\right)$ and at $R 5\left(R^{2}=0.99\right)$ (Figure 4). However, the distribution of $\mathrm{N}$ in different organs was variable at $\mathrm{R} 5$ because, as already mentioned, the $\mathrm{N}$ content of the pods was higher in treatments with fewer plants per meter (Figure 3).

The highest yield was observed in the inoculated treatment with $0.5 \times 16$ plants (T4), followed by the non-inoculated control receiving $\mathrm{N}$ fertilizer at the same density (T2) and T3 and T6 (Table 2). Only at the lower density (T5) was a significant decrease in total grain production observed.

Finally, the number of grains per plant and the 100-grain weight in the inoculated treatments with lower number of plants per meter $[0.5 \times 4$ plants $(\mathrm{T} 3)$ and $1.0 \times 4$ plants (T5)] were higher than at the other densi-

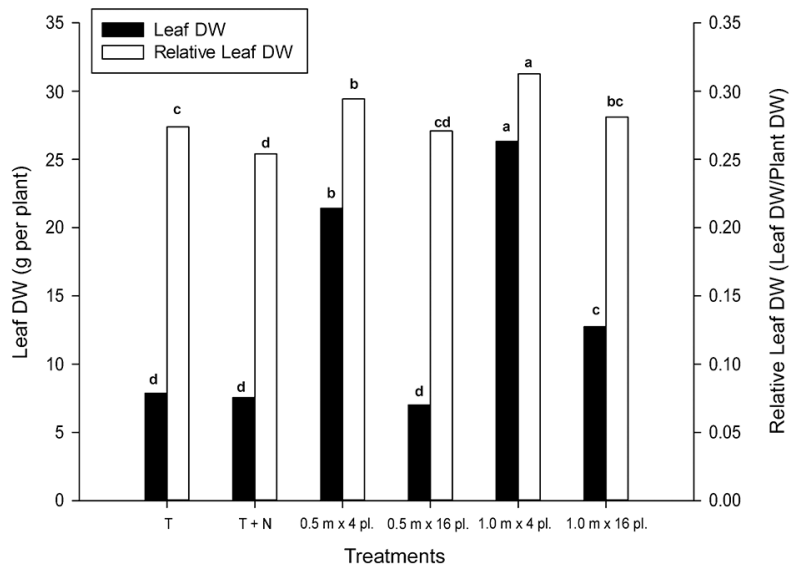

Figure 2 - Dry weight (DW) of leaflets per plant and relative dry weight of leaflet/total shoot dry weight at R5, as a function of plant density. Treatments: C, non-inoculated control; $\mathrm{C}+\mathrm{N}$, noninoculated control $+200 \mathrm{~kg}$ of $\mathrm{N} \mathrm{ha}^{-1}$, both with plant density of $0.5 \mathrm{~m} \times 16$ plants linear $\mathrm{m}^{-1}$. All other treatments were inoculated with Bradyrhizobium and sown at densities of $0.5 \mathrm{~m} \times 4$ plants, $0.5 \mathrm{~m} \times 16$ plants, $1.0 \mathrm{~m} \times 4$ plants and $1.0 \mathrm{~m} \times 16$ plants Different letters indicate differences ( $p \leq 0.05$, Fisher's test).

Table 1 - Effects of plant density on nodulation [nodule number, NN; dry weight per nodule, DWN; nodule dry weight, NDW; plant growth (shoot dry weight, SWD); nitrogen absorbed ( $\mathrm{N}$ abs) by soybean cultivar BRS 133 at the V4 and R5 stages. Experiment performed on an Oxisol with established population of bradyrhizobia $\left(\geq 10^{4}\right.$ cells $\mathrm{g}^{-1}$ ).

\begin{tabular}{|c|c|c|c|c|c|c|c|c|c|c|c|}
\hline Inoculation $^{\dagger}$ & Spacing $^{\ddagger}$ & Density & $\mathrm{NN}$ & DWN & NDW & SDW & $\mathrm{NN}$ & DWN & NDW & SDW & $\mathrm{N}$ abs \\
\hline & & & & & V4 - & 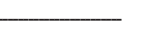 & & & $-\mathrm{R} 5$ & & \\
\hline & & plant & plant & $m g$ nod ${ }^{-1}$ & mg per plant & g per pl & $7^{\circ}$ pe & mg nod ${ }^{-1}$ & mg per & ant & $\mathrm{mg}$ \\
\hline T1-Control & $0.5 \times 16$ & 320,000 & $25.3 a^{\S}$ & $4.3 \mathrm{~b}$ & $110 \mathrm{a}$ & $2.09 \mathrm{~b}$ & $79.7 \mathrm{bc}$ & $6.5 \mathrm{~b}$ & $520 \mathrm{~b}$ & $28.48 c$ & \\
\hline T2-Control + N & $0.5 \times 16$ & 320,000 & $16.5 \mathrm{~b}$ & $2.6 \mathrm{c}$ & $40 \mathrm{c}$ & $2.62 a b$ & $60.6 c$ & $4.9 c$ & $300 c$ & $29.68 c$ & \\
\hline T3-Inoculated & $0.5 \times 4$ & 0 & 2 & $4.1 \mathrm{~b}$ & $100 \mathrm{ab}$ & $2.91 \mathrm{a}$ & 171 & a & $1340 \mathrm{a}$ & 0 a & $7 \mathrm{ab}$ \\
\hline T4-Inoculated & $0.5 \times 16$ & 320,000 & $26.4 \mathrm{a}$ & $5.0 \mathrm{a}$ & $130 \mathrm{a}$ & $2.60 a b$ & $89.4 \mathrm{~b}$ & $6.2 \mathrm{~b}$ & $540 \mathrm{~b}$ & $36.04 b c$ & $2.26 \mathrm{~b}$ \\
\hline T5-Inoculated & $1.0 \times 4$ & 40,000 & $24.2 \mathrm{a}$ & $4.0 \mathrm{~b}$ & $100 \mathrm{~b}$ & $3.15 a$ & $152.2 \mathrm{a}$ & $7.8 \mathrm{a}$ & $1180 \mathrm{a}$ & $84.58 \mathrm{a}$ & $3.56 \mathrm{a}$ \\
\hline T6-Inoculated & $1.0 \times 16$ & 160,000 & $21.5 \mathrm{ab}$ & $4.3 \mathrm{~b}$ & $90 \mathrm{~b}$ & $2.58 \mathrm{ab}$ & $99.7 \mathrm{~b}$ & $6.7 \mathrm{~b}$ & $670 \mathrm{~b}$ & $45.69 \mathrm{~b}$ & $3.41 \mathrm{a}$ \\
\hline
\end{tabular}

${ }^{\dagger}$ Non-inoculated control, with or without $\mathrm{N}$ fertilizer (200 kg of $\mathrm{N} \mathrm{ha}^{-1}$, split $50 \%$ at sowing and $50 \%$ at flowering); and inoculation with B. elkanii strains SEMIA 587 + SEMIA 5019, at the rate of $1.2 \times 10^{6}$ cells seed $^{-1}$; :Distance between lines $(\mathrm{m}) \times$ number of plants per linear meter; $\$$ Means $(n=6)$ within a column followed by different letters are different ( $p \leq 0.05$, Fisher's test). 


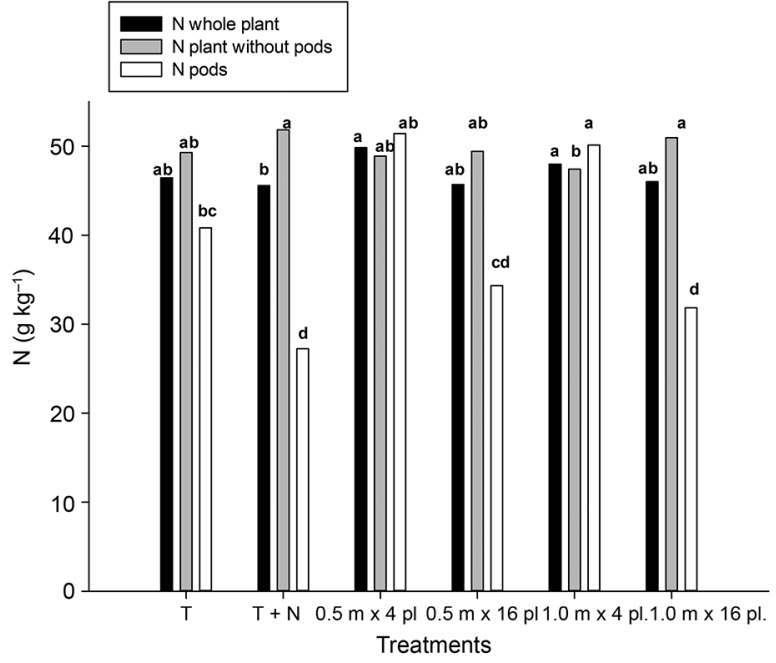

Figure 3 - Nitrogen ( $N$ ) content per kg of dry weight at R5, considering the whole plant, the plant without the pods and only the pods. Treatments as described in Figure 2. Different letters indicate differences ( $p \leq 0.05$, Fisher's test). ties $(p<0.0001)$ (Table 2). Significant correlations were found between the 100-grain weight parameter with nodule weight $(p \leq 0.0001)$, leaflets $(p \leq 0.0001)$, and pods $(p \leq 0.0004)$ (data not shown). However, no differences were observed in oil and protein contents between treatments, except in the extreme case of 40,000 plants ha ${ }^{-1}$ (Table 2).

\section{Discussion}

Soybean is exotic to Brazil, where the soils were originally devoid of compatible rhizobial strains capable of nodulating the legume (Ferreira and Hungria, 2002; Hungria et al., 2006a; Santos et al., 1999). However, the site where the experiment was conducted had been cropped for more than 20 years with soybean in the summer, always receiving inoculants containing soybean bradyrhizobia. Consequently, the highly naturalized bradyrhizobia population resulted in good nodulation even in the non-inoculated control, but $\mathrm{N}$-fertilizer clearly inhibited nodulation. The results from our study confirm previous reports on Brazilian soils (Hungria et
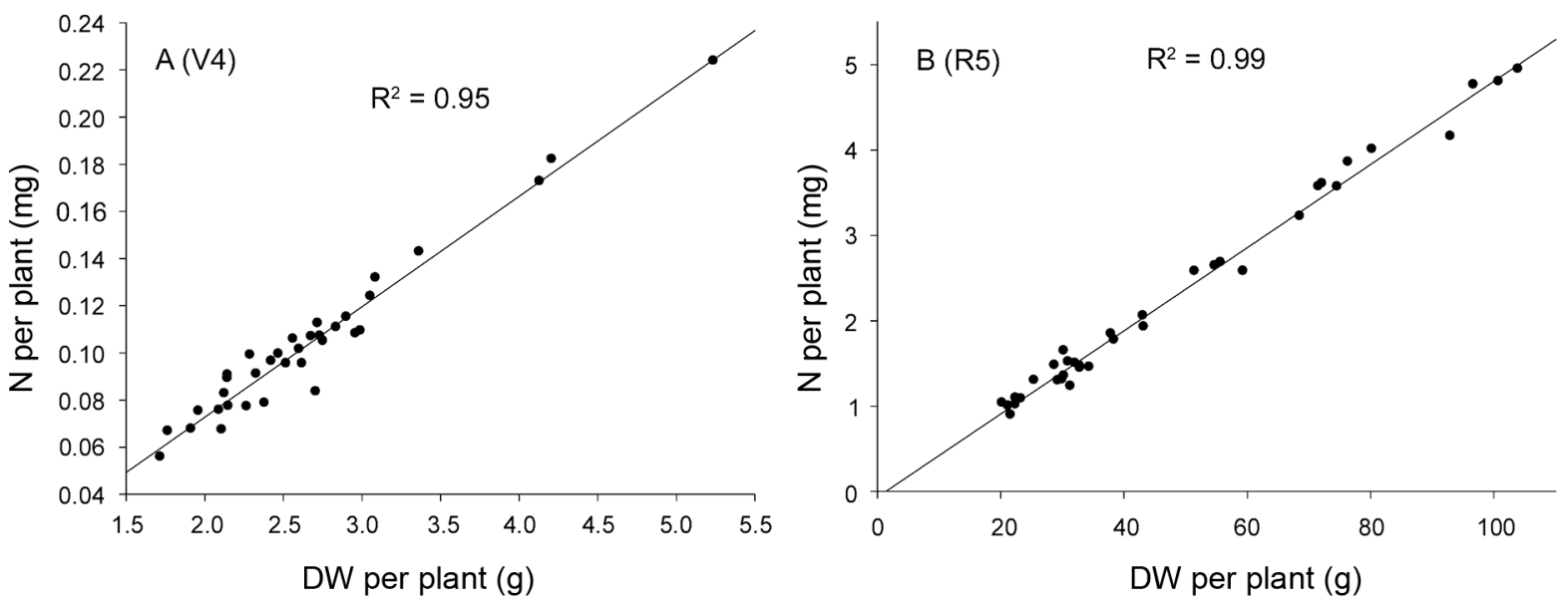

Figure 4 - Linear regression at V4 (A) and R5 (B) growth stages between shoot dry weight per plant, DW per plant (g); and $\mathrm{N}$ content per plant, $\mathrm{N}$ per plant (mg) of the plants from all treatments.

Table 2 - Effects of plant density on grain yield parameters of the soybean cultivar BRS 133.

\begin{tabular}{|c|c|c|c|c|c|c|c|c|}
\hline Inoculation $^{\dagger}$ & Spacing ${ }^{\ddagger}$ & Density§ & Density" & Yield & 100 grains & No. grains & Oil content & Protein content \\
\hline & & \multicolumn{2}{|c|}{ — plant per ha } & $\mathrm{kg} \mathrm{ha}^{-1}$ & g & $n^{0}$ per plant & 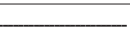 & $g^{-1}$ \\
\hline T1-Control & $0.5 \times 16$ & 320,000 & 361,700 & $3,160 \mathrm{ab}^{\dagger \dagger}$ & $14.4 \mathrm{~b}$ & $82.9 \mathrm{~d}$ & $230.2 \mathrm{ab}$ & $361.3 \mathrm{a}$ \\
\hline T2-Control + N & $0.5 \times 16$ & 320,000 & 328,400 & $3,240 a$ & $14.5 \mathrm{~b}$ & $87.6 \mathrm{~d}$ & $229.8 a b$ & $358.4 a b$ \\
\hline T3-Inoculated & $0.5 \times 4$ & 80,000 & 87,700 & $3,156 a b$ & $16.2 \mathrm{a}$ & $277.4 \mathrm{~b}$ & $227.5 \mathrm{ab}$ & 362.9 a \\
\hline T4-Inoculated & $0.5 \times 16$ & 320,000 & 361,900 & $3,334 a$ & $14.4 \mathrm{~b}$ & $76.6 \mathrm{~d}$ & $216.7 b$ & $361.5 \mathrm{a}$ \\
\hline T5-Inoculated & $1.0 \times 4$ & 40,000 & 42,100 & $2,137 c$ & $16.3 \mathrm{a}$ & $376.2 \mathrm{a}$ & $232.8 \mathrm{a}$ & $354.6 \mathrm{~b}$ \\
\hline T6-Inoculated & $1.0 \times 16$ & 160,000 & 177,100 & $3,004 \mathrm{~b}$ & $14.5 \mathrm{~b}$ & $135.8 \mathrm{c}$ & $228.1 \mathrm{ab}$ & $357.1 a b$ \\
\hline
\end{tabular}

${ }^{\dagger}$ Non-inoculated control, with or without $\mathrm{N}$ fertilizer (200 $\mathrm{kg}$ of N ha- ${ }^{-1}$, split $50 \%$ at sowing and $50 \%$ at flowering); and inoculation with B. elkanii strains SEMIA 587 + SEMIA 5019 , at the rate of $1.2 \times 10^{6}$ cells seed $^{-1}$; 'Distance between lines $(\mathrm{m}) \times$ number of plants per linear meter; $\$$ Theoeretical value; " ${ }^{9}$ Evaluation at harvest time, based on number of plants $\mathrm{m}^{-2}$; ${ }^{+1}$ Means $(n=6)$ from the same column followed by different letters are different $(p \leq 0.05$, Fisher's test). 
al., 2006a, 2006b, 2007; Mendes et al., 2004; Mercante et al., 2011) that reinoculation (inoculation every year) with elite strains can improve nodulation, nitrogen fixation rates and grain yield in soybean.

When the naturalized population was compared to the inoculation in plants with the same density of 320,000 plants $\mathrm{ha}^{-1}$, there was an increase in dry weight per nodule at V4 (Table 1), associated with large nodules at the root crown. At R5, no differences in nodulation were detected in the comparison of treatments differing in distance between rows $(0.5 \times 4$ plants and $1.0 \times 4$ plants), but on average, passing from 16 to 4 plants per linear meter in the inoculated treatments increased nodule dry weight at R5 by $108 \%$. The higher nodulation at R5 in the treatments with lower numbers of plants per linear meter, with no effect of the distance between planting rows could be explained by the higher dried leaflets weight (leaf blade without petiole) per plant, as well as by the partitioning of this plant biomass, consisting of higher leaf production in both treatments with 4 plants per linear meter, implying greater availability of photosynthates. In consequence, there might be greater availability of root exudates capable of promoting rhizobial growth in the rhizosphere, as well as $\mathrm{C}$ sources for the formation and functioning of the nodules, maintaining higher nitrogen fixation rates. Furthermore, the increased availability of $\mathrm{C}$ skeletons per plant would also facilitate the transport of ureides, the major nitrogenous compounds with low $\mathrm{C}: \mathrm{N}$ ratio synthesized in soybean nodules (Hungria et al., 2006b; Neves and Hungria, 1987). Altogether, these results provide strong evidence for the source/sink links between photosynthesis and nitrogen fixation (Kaschuk et al., 2009, 2012; Neves and Hungria, 1987).

The results obtained for biomass accumulation (SDW) and the patterns of $\mathrm{N}$ accumulation in tissues were similar to those reported for nodulation. These results indicate that plant biomass production at R5 was more affected by the number of plants per meter than by the distance between rows. Indeed, at R5, in the inoculated treatments, there was an average increase in SDW of $93 \%$ in treatments with 4 plants per linear meter, when compared with 16 plants per meter.

Besides the mechanisms of source/sink, another explanation for the higher nodulation and plant biomass in treatments with $0.5 \times 4$ plants and $1.0 \times 4$ plants might be related to qualitative differences in light, particularly in terms of the infrared/red relationship. In a study about the absorption, reflection and transmission of light from individual leaves of soybean, it has been reported that the majority of the blue and the red are absorbed, whereas much of the infrared is reflected or transmitted (Kasperbauer, 1987). Consequently, plants that grow in fields with little space between lines, or otherwise with high plant densities, receive higher ratios of infrared/red than those growing with greater distances between rows, or otherwise at lower densities (Kasperbauer, 1987). In turn, the infrared/red ratio influences various parameters of plant development, such as ultrastructure of the chloroplasts, the partitioning of carbohydrates to cells, photosynthetic efficiency, concentration of several metabolites, and partitioning between shoots and roots (Kasperbauer and Hamilton, 1984; Kasperbauer et al., 1984; Kasperbauer, 1987). Furthermore, there is also evidence of the control of nodulation by the phytochrome system, similarly favored by red light and inhibited by infrared radiation (Lie, 1969).

Regarding the efficiency of the nodules, treatments with 40,000 and 160,000 plant $^{-1}$ presented greater values of $\mathrm{N}$ per unit of nodule dry weight than plants with 320,000 plants ha $^{-1}$, probably due to increased supplies of photosynthates. Nodule dry weight was not correlated with plant biomass, or with the $\mathrm{N}$ accumulated at V4, but was significantly correlated at R5 (both with $p<$ 0.0001) (data not shown), indicating that increased nodule mass in low-density treatments was related to higher rates of nitrogen fixation. In contrast, Kapustka and Wilson (1990) found that an increase in soybean plant density reduced nodule number and dry weight per plant, but maintained high specific activity per nodule, which resulted in the same values of nitrogen fixation per plant.

In $\mathrm{R} 5, \mathrm{~N}$ content of the pods was higher in treatments with fewer plants per meter, which could be explained by the higher content of RuBisCO enzyme (ribulose-1,5-bisphosphate carboxylase oxygenase, E.C. number 4.1.1.39), which comprises about $50 \%$ of the total protein content in leaves and is also present in the pods, and thus represents an important source of $\mathrm{N}$ for mobilization (Schiltz et al., 2004). The amount and activity of RuBisCO are directly related to light quality, being superior in red light compared to infrared light (Eskins et al., 1991). Consequently, especially at advanced growth stages such as R5, one might assume that the content and activity of RuBisCO are higher in lower plant densities.

Crop yield data highlighted the fact that higher yields were observed in the inoculated or $\mathrm{N}$-fertilized treatments with $0.5 \times 16$ plants $\left(320,000\right.$ plants ha $\left.^{-1}\right)$ and, surprisingly, neither differed from the inoculated treatment with $0.5 \times 4$ plants, corresponding to only 80,000 plants $\mathrm{ha}^{-1}$. The yield at 80,000 plants $\mathrm{ha}^{-1}$ was also no different from that with $1.0 \mathrm{~m} \times 16$ plants $\left(160,000\right.$ plants ha $\left.{ }^{-1}\right)$; only at the lowest plant density, of 40.000 plants $\mathrm{ha}^{-1}$ was there a decrease $(p<0.0001)$ in total grain production. Consistent with these results, in an experiment conducted by Board (2000) in which three soybean densities (80,000, 145,000 and 390,000 plants $\mathrm{ha}^{-1)}$, were investigated yield was not affected by plant density, which was attributed to an equilibrium in the crop growth rate (CGR) at the beginning of the reproductive period, producing equivalent numbers of pods per square meter. Interestingly, the results from our experiment were obtained under adequate precipitation, and it is possible that an even better performance could have been obtained under water stress conditions; as pointed out before, at lower densities interplant competition for 
water might be mitigated (Andrade et al., 2002; Blumenthal et al., 1988). Another important comment is that nowadays there is pressure to increase soybean plant densities with the aim of generating higher yields; however, our results indicate that this might not be the best approach.

Both the number of grains per plant and the 100-grain weight in the inoculated treatments were higher at a spacing of $0.5 \mathrm{~m}$. BRS 133 is a high-yield cultivar $(p<0.0001)$. These results indicate that, under favorable $\mathrm{C} / \mathrm{N}$ source/sink conditions, it is possible to improve expression of the genetic potential of the cultivar. The lower number of plants per meter allowed for the largest individual plant growth and higher photosynthetic rate per plant which, in turn, demanded a greater supply of $\mathrm{N}$ through biological fixation. On the other hand, at higher densities, photosynthetic rates per plant were lower, as were nitrogen fixation inputs per plant. These results are consistent with studies of photosynthetic rate reduction, in which manipulations of the source, such as shading and defoliation, resulted in reductions in the number and dry weight of grains per plant (Egli, 2010; Proulx and Naeve, 2009). Additionally, with decreases in the supply of photosynthates (source) caused by the same treatments there were decreases in the rates of nitrogen fixation (Neves and Hungria, 1987).

In our experiment, shading did not change oil content between treatments $(p=0.4977)$, except in the extreme case of 40,000 plants $\mathrm{ha}^{-1}$, which resulted in higher values. Proulx and Naeve (2009) observed that shading caused greater decreases than defoliation, whereas Butler et al. (2010) found no differences in linoleic acid content at densities ranging from 185,000 to 556,000 plants $\mathrm{ha}^{-1}$. Altogether, these results indicate that in general, neither protein nor oil content are affected by density, except in very low plant populations, as shown in our study, and probably in very high populations too.

\section{Conclusions}

At lower plant densities the photosynthetic rate per plant increased and, consequently, higher $\mathrm{C}$ supply to the nodules resulted in increases in nodulation and in nitrogen fixation rates. The number of plants per linear meter was a stronger factor than the distance between rows, especially at R5, indicating greater importance of source/sink mechanisms at later stages of plant growth, when quantitative and qualitative factors (e.g. infrared/ red ratio) affecting light become decisive. Soybean had the potential to at least quadruple both photosynthesis and biological nitrogen fixation at lower plant densities. It is also worth mentioning the implications related to the cost of using four times more seeds and inputs, particularly pesticides, at sowing, as similar yields can be achieved with much lower plant densities than those recommended today, with important environmental and economic implications.

\section{Acknowledgments}

The study was partially supported by the Brazilian National Council for Scientific and Technological Development (CNPq), Project Repensa (562008/2010-1). Authors acknowledge Dr. Allan R.J. Eaglesham for English review and suggestions and Dr. Glaciela Kaschuk for suggestions on the manuscript. M.J. de Luca acknowledges a fellowship from CNPq (370481/2012-7) and $\mathrm{M}$. Hungria is also a research fellow from $\mathrm{CNPq}$ (300547/2010-2). Manuscript approved for publication by the Editorial Board of Embrapa Soja (17/2012).

\section{References}

Andrade, F.H.; Calviño, P.; Cirilo, A.; Barbieri, P. 2002. Yield responses to narrow rows depend on increased radiation interception. Agronomy Journal 94: 975-980.

Blumenthal, M.J.; Quach, V.P.; Searle, P.G.E. 1988. Effect of soybean population density on soybean yield, nitrogen accumulation and residual nitrogen. Australian Journal of Experimental Agriculture 28: 99-106.

Board, J. 2000. Light interception efficiency and light quality affect yield compensation of soybean at low lant populations. Crop Science 40: 1285-1294.

Board, J.; Harville, B.G.; Saxton, A.M. 1990. Branch and dry weight in relation to yield increase in narrow-row soybean. Agronomy Journal 82: 540-544.

Board, J.; Kamal, M.; Harville, B.G. 1992. Temporal importance of greater light interception to increased yield in narrow-row soybean. Agronomy Journal 84: 575-544.

Butler, J.A.; De Bruin, J.L.; Pedersen, P. 2010. Plant density effect on reduced linolenic acid soybean cultivars. Agronomy Journal 102: 348-354.

Egli, D.B. 2010. Soybean reproductive sink size and short-term reductions in photosynthesis during flowering and pod set. Crop Science 50: 1971-1977.

Empresa Brasileira de Pesquisa Agropecuária [Embrapa]. 2011. Tecnologies of soybean Production: Central Region of Brazil 2012-2013 = Tecnologias de Produção de Soja: Região Central do Brasil 2012 e 2013. Embrapa Soja, Londrina, PR, Brazil.

Eskins, K.; Jiang, C.Z.; Shibles, R. 1991. Light-quality and irradiance effects on pigments, light-harvesting proteins and Rubisco activity in a chlorophyll- and light- harvesting-deficient soybean mutant. Physiologia Plantarum 83: 47-53.

Fehr, W.; Caviness, C.; Burmood, D.T.; Pennington, J.S. 1971. Stage of development descriptions for soybeans, Glycine max (L) Merrill. Crop Science 11: 929-931.

Ferreira, M.C.; Hungria, M. 2002. Recovery of soybean inoculant strains from uncropped soils in Brazil. Field Crops Research 79: 139-152.

Hungria, M.; Campo, R.J.; Mendes, I.C. 2007. The Importance of Biological Nitrogen Fixation Process with the Soybean Crop: Major Component of the Competitiveness of the Brazilian Product $=$ A Importância do Processo de Fixação Biológica do Nitrogênio para a Cultura da Soja: Componente Essencial para a Competitividade do Produto Brasileiro. Embrapa Soja, Londrina, PR, Brazil. 
Hungria, M.; Campo, R.J.; Mendes, I.C.; Graham, P.H. 2006a. Contribution of biological nitrogen fixation to the $\mathrm{N}$ nutrition of grain crops in the tropics: the success of soybean (Glycine max L Merr.) in South America. p. 43-93. In: Singh, R.P.; Shankar, N.; Jaiwal, P.K., eds. Nitrogen nutrition and sustainable plant productivity. Studium Press, Houston, TX, USA.

Hungria, M.; Franchini, J.C.; Campo, R.J.; Crispino, C.C.; Moraes, J.Z.; Sibaldelli, R.N.R.; Mendes, I.C.; Arihara, J. 2006b. Nitrogen nutrition of soybean in Brazil: contributions of biological $\mathrm{N}_{2}$ fixation and of $\mathrm{N}$ fertilizer to grain yield. Canadian Journal of Plant Science 86: 927-939.

Hungria, M.; Franchini, J.C.; Campo, R.J.; Graham, P.H. 2005. The importance of nitrogen fixation to soybean cropping in South America. p. 25-42. In: Werner, W.; Newton, W.E., eds. Nitrogen fixation in agriculture, forestry, ecology and the environment. Springer, Dordrecht, The Netherlands.

Kapustka, L.A.; Wilson, K.G. 1990. The influence of soybean planting density on dinitrogen fixation and yield. Plant and Soil 129: 145-156.

Kaschuk, G.; Kuyper, T.W.; Leffelaar, P.A.; Hungria, M.; Giller, K.E. 2009. Are the rates of photosynthesis stimulated by the carbon sink strength of rhizobial and arbuscular mycorrhizal symbioses? Soil Biology \& Biochemistry 41: 1233-1244.

Kaschuk, G.; Leffelaar, P.A.; Giller, K.E.; Alberton, O.; Hungria, M.; Kuyper, T.W. 2010. Responses of grain legumes to rhizobia and arbuscular mycorrhizal fungi: a meta-analysis of potential photosynthate limitation of symbioses. Soil Biology \& Biochemistry 42: 125-127.

Kaschuk, G.; Yin, X.; Hungria, M.; Leffelaar, P.A.; Giller, K.E.; Kuyper, T.W. 2012. Photosynthetic adaptation of soybean due to varying effectiveness of $\mathrm{N}_{2}$ fixation by two distinct Bradyrhizobium japonicum strains. Environmental and Experimental Botany 76: 1-6.

Kasperbauer, M.J. 1987. Far-red light reflection from green leaves and effects on phytochrome-mediated assimilate partitioning under field conditions. Plant Physiology 85: 350-354.

Kasperbauer, M.J.; Hamilton, J.L. 1984. Chloroplast structure and starch grain accumulation in leaves that received different red and far-red levels during development. Plant Physiology 74: 967-970.

Kasperbauer, M.J.; Hunt, P.G.; Sojka, R.E. 1984. Photosynthate partitioning and nodule formation in soybean plants that received red or far-red light at the end of the photosynthetic period. Physiologia Plantarum 61: 549-554.

Lie, T.A. 1969. Non-photosynthetic effects of red and far-red light on root-nodule formation by leguminous plants. Plant and Soil 30: 391-404.
Mendes, I.C.; Vargas, M.A.T.; Hungria, M. 2004. Establishment of Bradyrhizobium japonicum and B. elkanii in a Brazilian Cerrados oxisol. Biology and Fertility of Soils 40: 28-35.

Mercante, F.M.; Hungria, M.; Mendes, I.C.; Reis Junior, F.B. 2011. Strategies to Improve the Efficiency of Microbial Inoculants with the Soybean Crop = Estratégias para Aumentar a Eficiência de Inoculantes Microbianos na Cultura da Soja. Embrapa Agropecuária Oeste, Dourados, MS, Brazil.

National Soybean Research Laboratory 2012. Soybean production basics. Available at: http://www.nsrl.illinois.edu/general/ soyprod.html [Accessed Sep 28, 2012]

Neves, M.C.P.; Hungria, M. 1987. The physiology of nitrogen fixation in tropical grain legumes. Critical Reviews in Plant Science 6: 267-321.

Paul, M.J.; Foyer, C.H. 2001. Sink regulation of photosynthesis. Journal of Experimental Botany 52: 1383-1400.

Penning de Vries, F.W.T.; Brunsting, A.H.M.; van Laar, H.H. 1974. Products, requirements and efficiency of biosynthesis: a quantitative approach. Journal of Theoretical Biology 45: 339377.

Pons, T.L.; Pearcy, R.W. 1994. Nitrogen reallocation and photosynthetic acclimation in response to partial shading in soybean plants. Physiologia Plantarum 92: 636-644.

Proulx, R.A.; Naeve, S.L. 2009. Pod removal, shade, and defoliation effects on soybean yield, protein, and oil. Agronomy Journal 101: 971-978.

Santos, M.A.; Vargas, M.A.T.; Hungria, M. 1999. Characterization of soybean bradyrhizobia strains adapted to the Brazilian Cerrados Region. FEMS Microbiology Ecology 30: 261-272.

Schiltz, S.; Gallardo, K.; Huart, M.; Negroni, L.; Sommerer, N.; Burstin, J. 2004. Proteome reference maps of vegetative tissues in pea: an investigation of nitrogen mobilization from leaves during seed filling. Plant Physiology 135: 2241-2260.

Stockman, Y.M.; Shibles, R, 1986. Soybean pod and flower abscission as influenced by carbohydrate supply durind flowering. Iowa State Journal of Research 61: 35-48.

Vincent, J.M. 1970. A Manual for the Pratical Study of RootNodule Bacteria. Blackwell Scientific, Oxford, UK. (IBP Handbook, 15).

Williams, L.E.; Dejong, T.M.; Phillips, D.A. 1982. Effect of changes in shoot carbon-exchange rate on soybean root nodule activity. Plant Physiology 69: 432-436.

Zenebon, O.; Pascuet, N.S.; Tigela, P. 2008. Physical-Chemical Methods for Food Analyses = Métodos Físico-Químicos para Análise de Alimentos.. 4ed. Instituto Adolfo Lutz, São Paulo, SP, Brazil. 